\title{
IN THE NAME OF PUBLIC PROCUREMENT LIBERALISATION: THE INTERACTION BETWEEN THE WTO'S GOVERNMENT PROCUREMENT AGREEMENT AND INTERNATIONAL, REGIONAL AND DOMESTIC INSTRUMENTS - THREE SHADES OF SYNERGY
}

\author{
Zena Prodromou*
}

\begin{abstract}
Summary: Public procurement liberalisation under the WTO's Government Procurement Agreement (GPA) is a gradual and evolving process. In parallel with this process, however, the interests of public procurement liberalisation are also served through the interaction of the GPA with other international, regional and domestic instruments. The paper presents and analyses three such instances of synergy created as a result of this interaction, all of which assist in the better application, implementation and enforcement of the principles proclaimed and the provisions enshrined under the GPA. First, the principles, standards and procedures of the GPA are promoted through a number of international and regional texts, including model laws and soft law instruments. Second, the successful enforcement of GPA relies on the remedies systems available under domestic legal orders. Third, the possible improvement of the remedies system under the GPA may be inspired by similar templates offered under other international and regional systems. Against this background, the paper concludes by remarking that the end goal of public procurement liberalisation relies on the synergies generated from the dialogue and interaction between the actual text of the WTO's GPA and the relevant international, regional and domestic instruments and does not necessarily rest on the concessions achieved in the context of the WTO's GPA itself.
\end{abstract}

\section{Introduction}

Public procurement liberalisation under the WTO's Government Procurement Agreement (GPA) is a gradual and evolving process. Each time, each negotiation results in more concessions and aims to bring further sectors under the Agreement's ambit and to draw more participants. Starting from this basic premise, the present paper seeks to assert whether in the process of the GPA's development its text interacts with other international, regional or domestic instruments in such a man-

"Lawyer, LLM, admitted to the Thessaloniki Bar. This research was supported in part by the Harvard Law School Summer Academic Fellowship programme. The author expresses her gratitude to Professor Marc Wu for his support, time and advice. 
ner that the interests of public procurement liberalisation are further enhanced and promoted. The paper argues that there are three specific instances that explicitly support this proposition.

The paper starts off by offering an overview of the history and main characteristics of the GPA. This analysis is not presented in a vacuum. On the contrary, it seeks to prove that a step-by-step approach towards public procurement liberalisation has been taken by the WTO under the GPA. The paper goes on to argue that while public procurement liberalisation under the GPA evolves, its goals are also assisted, promoted and furthered with its interaction with other international, regional and domestic instruments. Thus, the article traces and analyses three instances of such synergies. First, the principles, standards and procedures of the GPA are considered which are promoted through a number of international and regional texts, including model laws and soft-law instruments. Second, it is held that the successful enforcement of the GPA relies on the remedies systems available under domestic legal orders. It is then argued that a possible improvement of the remedies system under the GPA may be inspired by similar templates offered under other international and regional systems.

Against this background, the article concludes by arguing that the end goal of public procurement liberalisation is neither a sprint nor a one-man show. Its success depends rather on a long process of evolution and development where the GPA interacts with various international, regional and domestic texts, thus creating synergies that are pivotal in implementing its enshrined principles and in the enforcement of its very provisions. 


\section{Landmark steps towards public procurement liberalisation in the context of the WTO}

\subsection{The GPA: Its architecture and evolution from 1979 to $1994^{1}$}

The GPA's architecture and structure rest on seven pillars. First, the GPA initially took and still has the form of a plurilateral agreement, meaning that it is binding only on those WTO members that have decided to join it. Second, it relies on two fundamental principles, namely those of national treatment and non-discrimination. Third, the Agreement lays out specific requirements and standards for the procurement procedure, thus seeking to guarantee that public tendering is conducted in a transparent and competitive manner. Fourth, the GPA started out as an agreement of limited scope, meaning that only specific types of purchases conducted by specific governmental entities were intended to be caught under it. Fifth, the GPA's text lays out its general principles and goals. In contrast, the different obligations each member state commits to undertake under the GPA's provisions are defined and further specified in Schedules attached thereto. ${ }^{2}$ Sixth, each party is free to exclude the application of the Agreement in respect of specific areas, as well as vis-à-vis specific other parties. For example, Matsushita, Shoenbaum and Mavroidis use the reciprocal exemptions initially applied between the US

\footnotetext{
See generally Bernard Hoeckman and Petros Mavroidis (eds), Law and Policy in Public Purchasing: The WTO Agreement on Government Procurement (University of Michigan Press 1997); Sue Arrowsmith, The Law of Public and Utilities Procurement (Sweet \& Maxwell 1996, ch 15); Sue Arrowsmith and Arwel Davies (eds), Public Procurement Global Revolution (Kluwer Law International 1998); Sue Arrowsmith, John Linarelli and Don Wallace, Regulating Public Procurement: National and International Perspectives (Kluwer International 2000); Adrian Brown and Craig Pouncy, 'Expanding the International Market for Public Procurement: The WTO's Agreement on Government Procurement' (1995) 3 International Trade Law Review 69; G de Graaf and PA Trepte, 'The Revised GATT Procurement Agreement' (1997) 6 Public Procurement Law Review CS70; G de Graaf and M King 'Towards a More Global Government Procurement Market: The Expansion of the GATT Government Procurement Agreement in the Context of the Uruguay Round' (1995) 29(2) The International Lawyer 435; Auge Haagsma, 'Gordian Knots in Relation to the GPA: Myth or Reality?' in Laurence Gormley (ed), Gordian Knots in European Public Procurement Law (Bundesanzeiger 1996); Bernard Hoeckman and Petros Mavroidis, 'The WTO's Agreement on Government Procurement: Expanding Disciplines, Declining Membership?' (1995) 4 Public Procurement Law Review 63; Pablo Olivera, 'Defining the Scope of Covered Entities under the WTO Agreement on Government Procurement and the EC Procurement Rules' (1997) Public Procurement Law Review 1; Hans-Joachim Priess 'Public Procurement Law in the European Union: The New GATT Agreement on Government Procurement' (1996) 2 International Trade Law Review 51; Arie Reich 'The New GATT Agreement on Government Procurement: The Pitfalls of Plurilateralism and Strict Reciprocity' (1997) 31 Journal of World Trade 126; Robert Anderson 'Current Developments on Public Procurement in WTO' (2006) 15(6) Public Procurement Law Review NA 167.

2 World Trade Organization, Agreement on Government Procurement, 1869 UNTS 508. Overview available at <https://www.wto.org/english/tratop_e/gproc_e/gp_app_agree_e. htm $>$ accessed 18 December 2015.
} 
and Japan and the US and Norway in the context of the GPA to illustrate the way in which the exemption systems works under the GPA. ${ }^{3}$ Last, the GPA includes a 'built-in agenda' for the text's improvement, which is substantiated inter alia through extensions of its coverage and the further elimination of any remaining discriminatory measures.

In this context, the major challenge regarding the GPA has historically been its expansion, both in terms of the member states' participation thereto and regarding its scope and coverage. ${ }^{4}$ Consequently, the GPA does not constitute an instrument that promotes public procurement liberalisation in a block form all at once. This is reflected in its history.

The first agreement on governmental procurement was concluded in 1979 during the Tokyo Round of multilateral trade negotiations. ${ }^{5}$ The text proclaimed the fundamental principles upon which the Agreement was premised and the goals this sought to serve. It further envisaged a number of administrative requirements and procedures that came with the aim of harmonising the procurement procedure among WTO members who were party to the Agreement and of ensuring that the relevant processes were to be conditioned by transparency. Its material as well as its subjective scope was extremely limited.

The Tokyo Agreement was modified for the first time in $1988 .{ }^{6}$ The introduced amendments mainly sought to broaden the Agreement's scope. More specifically, the Agreement was extended to cover any kind of procurement activity (including purchases, leases, rentals and hire purchase contracts) instead of only specific types of procurement as per the previous regime. Moreover, the Agreement's scope was widened to the extent that the threshold of covered purchases was lowered to SDR 130,000 . What is more, locally established suppliers would now also be able to benefit from national treatment and non-discrimination principles. Further, the amended Agreement also added changes seeking to ensure that the procurement procedure was conditioned by enhanced

\footnotetext{
3 Mitsu Matsushita, Thomas J Schoenbaum and Petros C Mavroidis, The World Trade Organization (OUP 2006) 745.

4 Sue Arrowsmith, Government Procurement in the WTO (Kluwer Law International 2003); Robert Anderson, 'Current Developments on Public Procurement in the WTO' (2006) 6 Public Procurement Law Review NA 167; Anne Blank and Gabrielle Marceau, 'The History of the Government Procurement Negotiations since 1945' (1996) 5 Public Procurement Law Review 77.

5 World Trade Organization, Agreement on Government Procurement. Text available at <https://www.wto.org/english/docs_e/legal_e/tokyo_gpr_e.pdf> accessed 18 December 2015.

6 World Trade Organization, Agreement on Government Procurement, Revised Text of 1988. Text available at <https://www.wto.org/english/tratop_e/gproc_e/gpa_rev_ text_1988_e.pdf> accessed 18 December 2015.
} 
transparency. In so doing, a clear requirement was introduced stipulating that procurement entities should not request or receive advice from directly interested enterprises with regard to the technical standards to be implemented. ${ }^{7}$

Further negotiations took place in the context of the Uruguay Round with the aim of bringing forward further extensions regarding the Agreement's scope and coverage. As a result, a new GPA was agreed upon on 15 December 1993 and signed in Marrakesh in April 1994. ${ }^{8}$ The 1994 amendments extended the GPA's coverage (i) to also capture services and specified works, and (ii) to apply to local governments, including subnational governmental authorities.

The focus of the above analysis reflects the way in which public procurement liberalisation policy has been shaped in the context of the WTO. The 1979 Agreement merely served as the first step towards public procurement liberalisation. It was a small-scale experiment implemented for the types of purchases and governmental entities each party felt more comfortable opening up to in order to test any possible benefits generated from liberalisation. Following this trend, each new amendment or revision of the Agreement has in essence sought to bring more types of purchases under its ambit by relying on the perception that the benefits flowing from the GPA would lure more WTO member states into adhering to the Agreement and more GPA parties into submitting additional materials to the Agreement's scope. Based on the above, it becomes evident that the overall objective of public procurement liberalisation has not been proclaimed as a goal to be achieved overnight. On the contrary, it constitutes a long-term target to be attained through a long-running process of negotiation and implementation.

\subsection{And then came the revised GPA: from expansion to modernisation}

Within two years of the implementation of GPA 1994, the GPA parties started once again renegotiating the GPA's text according to the respective built-in provision of the 1994 Agreement. The negotiation was concluded in December 2011 and the outcome was formally adopted in March 2012. The revised WTO GPA entered into force on 6 April 2014. ${ }^{9}$

\footnotetext{
7 Matsushita,Schoenbaum and Mavroidis (n 3) 744.

8 World Trade Organization, The 1994 Agreement on Government Procurement. Text available at <https://www.wto.org/english/docs_e/legal_e/gpr-94_01_e.htm> accessed 18 December 2015.

$9 \quad$ World Trade Organization, 'Revised WTO Agreement on Government Procurement Enters into Force' (News Items, 7 April 2014) <https://www.wto.org/english/news_e/news14_e/ gpro_07apr14_e.htm> accessed 18 December 2015. See Section 3.1.2 below.
} 
The conclusion of the revised GPA constitutes a landmark in the timeline of public procurement liberalisation. The revised GPA marks the end of what was nearly 10 years of negotiation. From a substantive point of view, the revised GPA contributes to the expansion, modernisation and simplification of public procurement liberalisation. ${ }^{10}$

In line with the past amendments, the revised GPA extends and expands the Agreement's coverage and scope. In particular, the revised GPA now includes 150 additional central government entities in the European Union as well as certain sub-central government agencies. ${ }^{11}$ What is more, the Agreement's scope has once more been broadened to fully cover construction service contracts and service contracts. At the same time, certain parties to the revised GPA agreed to cover 'Build-OperateTransfer' contracts and also agreed to lower the monetary thresholds for already covered contracts.

The revised GPA further serves the goal of facilitating future parties' accession thereto. ${ }^{12}$ In particular, the relevant literature picks up four different ways in which the revised GPA is considered to contribute towards additional parties' participation. First, by increasing the sum of market access opportunities available by virtue of the agreement, the revised GPA presents prospective parties with additional benefits and opportunities. Second, the GPA's special and differential treatment provision has been revised in such a way that it offers 'an array of possible transitional measures that can be tailored to the needs of specific acceding parties without eroding the principles of reciprocity'. ${ }^{13}$ Therefore,

\footnotetext{
10 See Section 3.1.2 below.

11 See generally, for a particular focus on the debate regarding the GPA's coverage of Canada's central governmental agencies, David Collins, 'Canada's Sub-Central Coverage Under the WTO Agreement on Government Procurement' (2008) 17(1) Public Procurement Law Review 21.

12 Valeria Guimaraes de Lima e Silva, "The Revision of the WTO Agreement on Government Procurement: To What Extent Might It Contribute to the Expansion of Current Membership?' (2008) 17(2) Public Procurement Law Review 61: Guimaraes argues that the improvements to the agreement benefit current members more than they stimulate further accessions. There should be a shift from the emphasis on transparency towards a direct emphasis on market access.

13 Based on its development needs, and with the agreement of the parties, a developing country may adopt or maintain one or more of the following transitional measures, during a transition period and in accordance with a schedule, set out in its relevant annexes to Appendix I, and applied in a manner that does not discriminate among the other parties: a price preference programme, provided that the programme provides a preference only for the part of the tender incorporating goods or services originating in the developing country applying the preference or goods or services originating in other developing countries in respect of which the developing country applying the preference has an obligation to provide national treatment under a preferential agreement, provided that where the other developing country is a party to this Agreement, such treatment would be subject to any conditions set by the Committee; and is transparent, and the preference and its application in the procurement are clearly described in the notice of intended procurement; an offset,
} 
developing countries have extra interest to accede to the GPA now that the greatest variety of transitional measures is available to them. Next, the revised GPA is conditioned overall by further flexibility, the lack of which was one of the major concerns developing countries repeatedly raised against the previous GPA. Last, the profile of the Agreement has been raised further by virtue of its revision in such a way that it might exercise a psychological effect on WTO members who are not party to the Agreement, urging them to accede.

Following the above thoughts, it comes as no surprise that a substantial number of WTO members have recently expressed their interest in joining the GPA. Two additional WTO members, Montenegro and New Zealand, acceded formally to the revised GPA on 15 June 2015 and 13 July 2015, respectively. ${ }^{14}$ At the same time, the WTO's Committee on Government Procurement has reported substantial progress in negotiations with WTO members seeking accession to the GPA. To name just a few, Ukraine submitted to the Committee a draft final offer on 26 May 2015, Costa Rica and Thailand have applied for observer status in the committee, while Australia recently launched its bid to join the GPA. ${ }^{15}$

The changes to the GPA revealed so far fall squarely under the previously noted attempts to develop and broaden the Agreement's subject matter, as well as its material and personal scope. What differentiates the 2014 Agreement from its previous amendments, though, is that this time the text has been completely revised so that the structure is simplified and the text is modernised overall.

First of all, the text of the 2014 GPA clarifies and simplifies the relevant provisions and terms. In particular, the revised GPA includes definitions of the relevant terms for the first time and restructures the stipulated rules and procedures with a view to making the text more understandable and user friendly. ${ }^{16}$

provided that any requirement for, or consideration of, the imposition of the offset is clearly stated in the notice of intended procurement; the phased-in addition of specific entities or sectors; and a threshold that is higher than its permanent threshold.

14 World Trade Organization, 'Montenegro and New Zealand to Join the WTO's Agreement on Government Procurement' (News Items, 29 October 2014) <https:/ /www.wto.org/english/news_e/news14_e/gpro_29oct14_e.htm>; World Trade Organization, New Zealand Ratifies Revised WTO Procurement Pact (News Items, 13 July 2015) <https://www.wto. org/english/news_e/news15_e/gpro_13jul15_e.htm; World Trade Organization, Montenegro Ratifies Revised WTO Procurement Pact' (News Items, 15 June 2015) <https://www. wto.org/english/news_e/news15_e/gpro_15jun15_e.htm> all accessed 18 December 2015. 15 World Trade Organization, 'Australia Launches Bid to Join Government Procurement Pact' (News Items, 3 June 2015) <https://www.wto.org/english/news_e/news15_e/ gpro_05jun15_e.htm> accessed 18 December 2015.

16 See generally Guimaraes de Lima e Silva (n 12). 
The revised text further seeks to modernise the Agreement's content and to 'tune' the parties' obligations to the current procuring practices. More specifically, the 2014 GPA seeks to serve the interests of public procurement policy modernisation through three different means. First, the revised GPA responds to the growing need for electronic public procurement. In so doing, Article VII. 1 of the revised Agreement stipulates that:

For each covered procurement, a procuring entity shall publish a notice of intended procurement in the appropriate paper or electronic medium listed in Appendix III, except in the circumstances described in Article XIII. Such medium shall be widely disseminated and such notices shall remain readily accessible to the public, at least until expiration of the timeperiod indicated in the notice.

Second, the 2014 GPA takes due account of the request for greater flexibility in the procuring procedure especially by reducing the notice time, provided that the relevant notices are posted electronically. Article XI.7 foresees respectively that:

Notwithstanding any other provision in this Article, where a procuring entity purchases commercial goods or services, or any combination thereof, it may reduce the time-period for tendering established in accordance with paragraph 3 to not less than 13 days, provided that it publishes by electronic means, at the same time, both the notice of intended procurement and the tender documentation. In addition, where the entity accepts tenders for commercial goods or services by electronic means, it may reduce the time-period established in accordance with paragraph 3 to not less than 10 days.

Last, the new GPA guarantees greater transparency regarding award information by explicitly laying out specific procedures for the publication of the award notices and the maintenance of relevant documentation. In particular, according to Article XVI:

\section{Publication of Award Information}

Not later than 72 days after the award of each contract covered by this Agreement, a procuring entity shall publish a notice in the appropriate paper or electronic medium listed in Appendix III. Where the entity publishes the notice only in an electronic medium, the information shall remain readily accessible for a reasonable period of time. The notice shall include at least the following information:

a description of the goods or services procured; 
the name and address of the procuring entity;

the name and address of the successful supplier;

the value of the successful tender or the highest and lowest offers taken into account in the award of the contract;

the date of award; and

the type of procurement method used, and in cases where limited tendering was used in accordance with Article XIII, a description of the circumstances justifying the use of limited tendering.

3. Maintenance of Documentation, Reports and Electronic Traceability

Each procuring entity shall, for a period of at least three years from the date it awards a contract, maintain:

the documentation and reports of tendering procedures and contract awards relating to covered procurement, including the reports required under Article XIII; and

data that ensure the appropriate traceability of the conduct of covered procurement by electronic means.

Following the above, the revised GPA of 2014 marks a new era in the field of public procurement liberalisation and policy. In the first instance, the revised GPA builds yet another step in the further expansion of the agreement. The agreement's scope has been widened, its coverage enlarged, and commentators remark that both the substance of the revised GPA provisions as well as the increased profile that flows as a result thereof create further incentives for WTO members who are not party to the Agreement to accede. Therefore, the revised GPA follows the same thread as the past amendments to the previous text of the GPA. At the same time, however, the GPA does not represent merely an expansion of the previous text but mainly a revision thereof with the aim of bringing it into line with the current requirements and realities of public procurement. Consequently, to the extent that the 2014 GPA further substantiates the fundamental principles and procedures upon which the parties' public procurement regimes are to be built, its text does not constitute an amendment to the previous Agreement but rather an effort to fundamentally streamline the Agreement's content to new procuring needs. Based on the above, the 2014 GPA represents a landmark in public procurement policy. Regardless of the actual assessment of the changes the revised GPA brings, the significance of the revised GPA stems from the fact that it constitutes the first attempt to modernise public procurement policy in the framework of the WTO 10 years after the GPA's introduction. ${ }^{17}$

17 See generally Arie Reich, 'The New Text of the Agreement on Government Procurement: An Analysis and Assessment' (2009) 12(4) Journal of International Economic Law 989. 
The above exposition and detailed description of the elements of the new GPA prove that the goal of public procurement liberalisation is being attained step by step. The more concessions are built in, the more procedures become simplified and clarified, and the more the requirements are modernised, then more sectors open up towards liberalisation and more WTO member states opt to adhere to similar processes. Consequently, the GPA constitutes an instrument that evolves and gradually changes shape and changes in detail with the aim of capturing an increasing number of public procurement liberalisation aspects, both regarding the subject matter covered as well as the parties involved.

\section{From stand-alone action to enhanced synergy: making a case for the promotion of public procurement liberalisation through the GPA's synergy with international, regional and domestic instru- ments}

Against the background of the stand-alone and gradual evolution of public procurement liberalisation under the WTO's GPA, the question arises as to whether any forces are available at an international, regional and domestic level that may assist in the promotion of the GPA principles or even towards their enforcement. The present paper argues that there are indeed three levels of synergy between the GPA and such instruments. At the first level, various international and regional texts promote principles, standards and procedures that are in line with the GPA's conditions and requirements regarding public procurement liberalisation. Second, the very enforcement of the GPA relies on the remedies systems available under domestic legal orders. And last, the possible improvement of the remedies system under the GPA may be inspired by similar templates offered under other international and regional systems. Consequently, the overall goal of public procurement liberalisation is being attained through the levels of synergy between the GPA and various international, regional and domestic organs.

\subsection{The first level of synergy: promoting principles, procedures and standards related to public procurement liberalisation through a number of international, regional instruments}

Interestingly, a series of international, regional and national instruments have the direct or indirect effect of promoting public procurement liberalisation. ${ }^{18}$ This is not to argue that these instruments necessarily have as their primary objective the liberalisation of procurement markets

18 See generally Robert Anderson, 'Renewing the WTO Agreement on Government Procurement: Progress to Date and Ongoing Negotiations' (2007) 16 Public Procurement Law Review 255 . 
or trade markets or even procurement as such. On the contrary, what the following analysis highlights and what the present article consequently submits is that public procurement liberalisation does not rest exclusively with the GPA. While this evolves and develops, there are a number of other instruments whose specific provisions promote and enhance principles, standards and procedures whose substance ties in with and serves the interests of public procurement liberalisation. An overview of the key aspects of the relevant instruments can illustrate what is suggested as the first level of synergy.

\subsubsection{The 2011 UNCITRAL Model Law on Public Procurement}

The Model Law on Public Procurement was first adopted in 1994 and its revised version was introduced in $2011 .{ }^{19}$ It is in essence a template drafted with the aim of assisting states in forming and adopting their public procurement regimes. ${ }^{20}$

According to its Guide to Enactment, the Model Law is intended to serve the objectives of: (a) achieving economy and efficiency; (b) wide participation by suppliers and contractors, with procurement open to international participation as a general rule; (c) maximising competition; (d) ensuring fair, equal and equitable treatment; (e) assuring integrity, fairness and public confidence in the procurement process; and (f) promoting transparency. ${ }^{21}$ In so doing, it contains a number of suggested procedures and principles aimed at achieving the aforementioned goals.

In particular, and by way of example, the Model Law guarantees the interested parties' right to information through prescribing specific procedures for the publication and communication of information related to forthcoming procurements. ${ }^{22}$ At the same time, it also seeks to streamline and rationalise the relevant decision-making by laying out specific rules and criteria for the award of contracts and the evaluation of tenders. ${ }^{23}$

19 UNCITRAL Model Law on Public Procurement (January 2011) <http://www.uncitral. org/pdf/english/texts / procurem/ml-procurement-2011/2011-Model-Law-on-Public-Procurement-e.pdf> accessed 18 December 2015.

20 See generally Caroline Nicholas, 'Framework Agreements and the UNCITRAL Model Law on Procurement' (2008) 5 Public Procurement Law Review NA 220; Caroline Nicholas, 'The UNCITRAL Model Law on Procurement: The Current Reform Programme' (2006) 6 Public Procurement Law Review NA 161; Caroline Nicholas 'Remedies for Breaches of Procurement Rules and the UNCITRAL Model Law on Procurement' (2009) 18(4) Public Procurement Law Review NA 151. For a comparison of the UNCITRAL Model Law with the EU Procurement Directive, see OECD, 'Comparison Between the EC Procurement Directive and the UNCITRAL Model Law’ (2000) 6 Public Procurement Law Review 287.

21 UNCITRAL, Guide to Enactment of the UNCITRAL Model Law on Public Procurement. <http://www.uncitral.org/pdf/english/texts/procurem/ml-procurement-2011/Guide-Enactment-Model-Law-Public-Procurement-e.pdf> accessed 18 December 2015.

22 Articles 6, 7 and 13 of the UNCITRAL Model Law on Public Procurement.

23 ibid, Arts 11, 42 et seq. 
Following the above, it is evident that the Model Law implicitly contributes to public procurement liberalisation by setting out a number of standards regarding the public procurement process, to which states opting to enact legislation under it need to adhere. In fact, in crafting the therein endorsed and envisaged standards, the Model Law takes into account the provisions of the WTO GPA, the EU directives (on procurement and remedies), the UN Convention Against Corruption, the Procurement Guidelines and the Consultant Guidelines of the World Bank and the equivalent documents of the IFIs.

It is estimated that approximately 30 states have already enacted legislation on the basis of the UNCITRAL Model Law template. ${ }^{24}$

\subsubsection{OECD: Recommendations and Peer Reviews}

The OECD aims to promote and safeguard international standards in the framework of public procurement. With this aim, the Organisation has issued a number of recommendations fleshing out the substance of the supported procurement policies. These texts include: (i) the OECD Recommendation on Enhancing Integrity in Public Procurement (2008); ${ }^{25}$ (ii) the Recommendation on Principles for Public Governance of PublicPrivate Partnerships (2012); ${ }^{26}$ (iii) the Recommendation on Fighting Bid Rigging in Public Procurement (2012);27 (iv) the Recommendation on Improving the Environmental Performance of Public Procurement (2002); ${ }^{28}$ and (v) the Recommendation on Anti-Corruption Proposals for Bilateral Aid Procurement (1996). ${ }^{29}$

\footnotetext{
24 EBRD UNCITRAL Public Procurement Initiative, '2011 UNCITRAL Model Law on Public Procurement'(2011) <http://www.ppi-ebrd-uncitral.com/index.php/uncitral-model-law> accessed 18 December 2015.

25 OECD, Recommendation of the Council on Enhancing Integrity in Public Procurement [C(2008)105] <http://www.oecd.org/governance/ethics/41549036.pdf> accessed 18 December 2015 .

26 OECD, Recommendation of the Council on Principles for Public Governance of PublicPrivate Partnerships [C(2012)86] <http://webnet.oecd.org/oecdacts/Instruments/ShowInstrumentView.aspx?InstrumentID=275\&InstrumentPID=281\&Lang=en\&Book=> accessed 18 December 2015.

27 OECD, Recommendation of the Council on Fighting Bid Rigging in Public Procurement [C(2012)115 - C(2012)115/CORR1 - C/M(2012)9] <http:/ /www.oecd.org/daf/competition/ RecommendationOnFightingBidRigging2012.pdf> accessed 18 December 2015

28 OECD, Recommendation of the Council on Improving the Environmental Performance of Public Procurement [C(2002)3] < http://acts.oecd.org/Instruments/ShowInstrumentView. aspx?InstrumentID=46\&InstrumentPID=43\&Lang=en\&Book=False $>$ accessed 18 December 2015 .

29 OECD, Recommendation on Anti-Corruption Proposals for Bilateral Aid Procurement [DCD/DAC(96)11/FINAL] <http://acts.oecd.org/Instruments/ShowInstrumentView.aspx? InstrumentID=203\&InstrumentPID=199\&Lang=en\&Book=> accessed 18 December 2015.
} 
In light of the above, the OECD has taken a number of steps with a view to supporting governments in implementing the aforementioned principles and aiming to ensure their due adoption. More specifically, the OECD has introduced an online toolbox available to policy makers that captures emerging good practice to enhance corruption prevention and good management in public procurement. ${ }^{30}$ What is more, states may benefit from peer reviews on the basis of which leading experts from OECD countries offer their experience regarding the implementation of international public procurement standards and best practices.

\subsubsection{World Bank Guidelines}

The World Bank constitutes yet another institution seeking to support the improvement of borrower countries' procurement systems through the promotion of sound public procurement policies and practices. First, the World Bank has issued detailed and specific Guidelines for the Procurement of Goods, Works and Non-Consulting Services Addressed to Borrowers under IBRD Loans and IDA Credits \& Grants. ${ }^{31}$ Pursuant to these, borrower countries are contractually obliged to take appropriate measures to reform and improve their public procurement systems and procedures as a condition to receiving funding from the World Bank.

Moreover, the World Bank has attempted to create international benchmarks in the field of public procurement through the creation of a dedicated report that presents a cross-country analysis reflecting how the private sector interacts in business dealings with the governments in 10 pilot economies. ${ }^{32}$

\subsubsection{UN Conventions and International Codes}

Last, the UN has equally adopted a number of conventions seeking to promote international standards of transparency and ethical conduct in the field of public procurement. ${ }^{33}$

\footnotetext{
30 OECD, Public Procurement Toolbox <http://www.oecd.org/governance/procurement/ toolbox/> accessed 18 December 2015.

31 World Bank, Guidelines on the Procurement of Goods, Works and Non-Consulting Services under IBRD Loans and IDA Credits \& Grants by World Bank Borrowers (2011) <http:// siteresources.worldbank.org/INTPROCUREMENT/Resources/278019-1308067833011/ Procurement_GLs_English_Final_Jan2011.pdf> accessed 18 December 2015.

32 World Bank, Benchmarking Public Procurement <http://rru.worldbank.org/PublicProcurement/> accessed 18 December 2015; World Bank, Benchmarking Public Procurement 2015 Pilot Report Assessing Procurement Systems in 10 Economies <http://rru. worldbank.org/Public-Procurement/ / media/GIAWB/PublicProcurement/Documents / Reports/Benchmarking-Public-Procurement-2015.ashx> accessed 18 December 2015.

33 United Nations Commission on International Trade Law, United Nations Convention against Corruption: Implementing Procurement-related Aspects <http:/ /www.uncitral.org/ pdf/english/workinggroups/wg_1/INF.2.pdf> accessed 18 December 2015.
} 
In particular, Article 9 of the United Nations Convention Against Corruption stipulates that:

Each State Party shall, in accordance with the fundamental principles of its legal system, take the necessary steps to establish appropriate systems of procurement, based on transparency, competition and objective criteria in decisionmaking, that are effective, inter alia, in preventing corruption.

What is more, the Convention foresees in the same Article that '[w] here appropriate, measures [shall be addressed] to regulate matters regarding personnel responsible for procurement, such as declaration of interest in particular public procurements, screening procedures and training requirements'.

At the same time, international standards relevant for public procurement procedures may be traced in a series of other UN Instruments. The UN International Code of Conduct for Public Officials is one such example. Jurich notes in respect thereto that although this 'is not specifically aimed at public procurement, it does (nonetheless) address conflicts of interest in general and contains common elements of monitoring'. ${ }^{34}$

\subsubsection{Conclusions}

It therefore flows from the above that a number of international and regional instruments create and promote international principles on good governance, transparency, anti-corruption and non-discrimination. These standards and principles form the very foundations of and preconditions for a rational, modernised and liberalised public procurement mechanism. Based on this observation, the current paper argues that the goal of public procurement liberalisation is being achieved through a dialogue between different sources of law within the international legal order. The particular and specific goals, standards and principles advanced by the GPA are being directly or indirectly reinforced by a number of other international instruments. It is thus clear that the objective of public procurement liberalisation is being substantiated through and advanced by synergy between different international instruments.

\subsection{The second level of synergy: safeguarding the GPA's en- forcement through actions brought before the domestic legal order}

Moving forward, the proper implementation of the public procurement liberalisation policy under the GPA relies on the remedies available under domestic legal orders. In substantiating this argument, the pre-

\footnotetext{
34 James Jurich, 'International Approaches to Conflicts of Interest in Public Procurement: A Comparative Review' (2012) 7(4) European Procurement \& Public Private Partnership Law Review 242.
} 
sent paper provides an overview of the different enforcement procedures available under the WTO, namely the standard DSU Procedure and the Bid Challenge System, before elaborating on how the instruments offered under the domestic legal orders secure the enforcement and thus the proper implementation of the GPA and subsequently the WTO's public procurement policy.

\subsubsection{The standard DSU procedure}

Under Article XX GPA, the standard DSU procedure constitutes one of the means to enforce the Agreement's provisions. In particular, the DSU provides a mechanism for the resolution of disputes between WTO members who are party to the Agreement. Consequently, the pre-contractual or contractual dispute between a bidder or provider and the contracting authority is transformed for the purposes of the DSU into a dispute between the parties' governments. Should a government decide to take up such a complaint lodged by its national bidder or provider against the authorities of another GPA party, it will first need to attempt to resolve the dispute in an amicable manner. If such a settlement between the parties cannot be reached, then the applicant state may request a panel to be established to hear the case. The panel's task is to provide a report to the parties concerned, which is then adopted by the DSU. The latter would then request the state in breach to repeal any or all measures that contravene the WTO principles. If the state fails to do so, then the DSB may authorise the unilateral suspension of the application of the GPA in the territory affected by the violation. ${ }^{35}$

Following the above, enforcing the GPA under the DSU presents two important shortcomings that go against the very nature and special characteristics of public procurement.

First, following the DSU's provisions, the GPA is implemented at an inter-governmental level: it is the WTO member who is party to the GPA that needs to bring a case against another WTO member who is party to the GPA on behalf of a private individual alleging infringements of the Agreement's provisions. Indeed, this is the standard procedure for the resolution of disputes under the WTO. However, it is not clear whether this general procedure adequately addresses the specificities of public procurement. This is so because public procurement takes place at an individual level: various contracting authorities in each of the GPA parties publish and conduct procurement procedures in the course of which individual bidders and contractors may observe irregularities contrary to the provisions of the GPA. In order for these irregularities to be brought against the infringing contracting authorities, though, the individual bidders need

35 Christopher Bovis, EC Public Procurement Law and Regulation (OUP 2006) 94. 
to pass the hurdle of convincing their national governments not only of the existence of a breach but also of the importance of bringing an action against another WTO member. It is therefore clear that the implementation of the GPA relies on the discretion of a national government which will naturally need to balance any political interests involved when deciding whether or not to act upon a bidder's or contractor's complaint. Even though this finding holds true for any procedure under the WTO's DSU, it is not clear whether a highly deferential procedure such as that under the DSU is indeed the best way to secure the implementation of parties' commitments and duties in the context of a policy that is as fragmented as the various individual procurement procedures of different contracting authorities in each of the WTO members who are parties to the GPA.

What is more, the DSU procedure aims to have the infringing party change its procurement policy and comply with the prescriptions of the GPA in the future. However, the DSU procedure does not provide for a specific remedy to repair the procuring opportunities lost as a result of the alleged breaches. For example, as Bovis notes, a panel may not order the re-tendering of a procedure vitiated by infringements of the GPA. ${ }^{36}$ Consequently, any sought remedies have a purely prospective nature instead of a reparatory or restitutional one.

It thus flows from the above that although the DSU procedure applicable to the GPA is fully in line with the general principles regarding the resolution of disputes in the context of the WTO, this may not represent the best available system to address the special particularities of public procurement policy and procedure.

\subsubsection{The bid challenge system ${ }^{37}$}

In order to remedy the aforementioned shortcomings, the GPA introduced what has been characterised as a unique feature within the WTO enforcement regime: the bid challenge system. Article XVIII of the revised GPA stipulates that:

1. Each Party shall provide a timely, effective, transparent and non-discriminatory administrative or judicial review procedure through which a supplier may challenge:

a. a breach of the Agreement; or

b. where the supplier does not have a right to challenge directly a breach of the Agreement under the domestic law of

\footnotetext{
36 ibid.

37 See generally Sue Arrowsmith, The Character and Role of National Challenge Procedure Under the Government Procurement Agreement' (2002) 11 Public Procurement Law Review 235; Arrowsmith, Linarelli and Wallace (n 1); Arie Reich, International Public Procurement Law: The Evolution of International Regimes on Public Purchasing (Kluwer International 1999) 307-312.
} 
a Party, a failure to comply with a Party's measures implementing this Agreement,

arising in the context of a covered procurement, in which the supplier has, or has had, an interest. The procedural rules for all challenges shall be in writing and made generally available.

\section{$(\ldots)$}

4 Each Party shall establish or designate at least one impartial administrative or judicial authority that is independent of its procuring entities to receive and review a challenge by a supplier arising in the context of a covered procurement.

\section{$(\ldots)$}

6. Each Party shall ensure that a review body that is not a court shall have its decision subject to judicial review or have procedures that provide that:

a. the procuring entity shall respond in writing to the challenge and disclose all relevant documents to the review body;

b. the participants to the proceedings (hereinafter referred to as 'participants') shall have the right to be heard prior to a decision of the review body being made on the challenge;

c. the participants shall have the right to be represented and accompanied;

d. the participants shall have access to all proceedings;

e. the participants shall have the right to request that the proceedings take place in public and that witnesses may be presented; and

f. the review body shall make its decisions or recommendations in a timely fashion, in writing, and shall include an explanation of the basis for each decision or recommendation.

Following the above, the bid challenge mechanism allows interested bidders to challenge procuring procedures that are in breach of the GPA before the competent bodies of the procuring state. ${ }^{38}$ This mechanism, which is sui generis by WTO standards, ${ }^{39}$ best safeguards the cor-

\footnotetext{
38 PA Messerlin, 'Agreement on Public Procurement' in OECD, The New World Trading System: Readings (OECD 1995) 65: 'this is a unique innovation in the GATT system; it is the first time that direct access to enforcement procedures under the regulations of the importing country has been granted to foreign firms within the context of a GATT text'.

39 Arrowsmith (n 4) 385 notes that the bid challenge system 'marks a departure from the approach of most other WTO agreements. In general these do not require affected private
} 
rect implementation and application of the GPA's provisions by shifting, in essence, the burden of GPA compliance monitoring and surveillance from national governments to interested stakeholders. This shift offers enhanced guarantees and assurances for the enforcement of the GPA: interested parties have both concrete and increased incentives for GPA rules to be observed. At the same time, they also have inside knowledge and experience on the procuring authorities' procedures and decisions. ${ }^{40}$ For example, Mosoti highlights the practical significance of bidders and contractors taking the lead in securing the GPA's enforcement, by noting that: "most violations of the WTO GPA take place at an individual level, therefore it is crucial that the applicant is in the position to challenge the procuring agency's award with regard to specific contracts'. ${ }^{41}$

Next to safeguarding the correct application and implementation of the GPA, the bid challenge provision also ensures that applicants have access to effective and timely remedies under domestic law. In particular, Article XVIII foresees that:

Each Party shall adopt or maintain procedures that provide for:

a. rapid interim measures to preserve the supplier's opportunity to participate in the procurement. Such interim measures may result in suspension of the procurement process. The procedures may provide that overriding adverse consequences for the interests concerned, including the public interest, may be taken into account when deciding whether such measures should be applied. Just cause for not acting shall be provided in writing; and

b. where a review body has determined that there has been a breach or a failure as referred to in paragraph 1, corrective action or compensation for the loss or damages suffered, which may be limited to either the costs for the preparation of the tender or the costs relating to the challenge, or both (emphasis added).

Therefore, in contrast to the remedies under the DSU system, the subject matter and nature of which is strictly prospective in nature, the

parties to be given a right to enforce WTO rules, but rely mainly on inter-governmental enforcement. Private challenge procedures are required under some of these provisions, but none go as far as the GPA. In particular, their procedural requirements and obligations on remedies are not as detailed or stringent as those of the GPA and they generally give greater deference to states' own national traditions of review in the particular area concerned'.

40 See, eg, Aaditya Mattoo, 'The Government Procurement Agreement: Implications of Economic Theory' (October 1996) WTO Staff Working Paper, No TISD-96-03 <http://hdl.handle.net/10419/90696> accessed 18 December 2015.

${ }^{41}$ Victor Mosoti, 'Reforming the Laws on Public Procurement in the Developing World: The Example of Kenya' (2005) 54(3) International and Comparative Law Quarterly 621. 
bid challenge system allows for timely remedies, which may also take the form of interim measures. This is extremely important, especially if one is to take into account the track record of cases brought under the DSU in which the panel ruled on violations of the GPA but nonetheless ended up merely accepting commitments that similar breaches would not be repeated in the future, due to the fact that the purchases under review had already been concluded. ${ }^{42}$ The importance of timely remedies for securing the correct implementation and enforcement of the GPA is captured by Mavroidis and Hoekman who remark that the nature of procurement is such that most of the time, unless rapid action can be taken, inconsistencies with the Agreement will de facto be tolerated as firms will not have an interest in bringing a case'. ${ }^{43}$

\subsubsection{Conclusions}

It therefore derives from the above that the bid challenge system before the competent bodies of the contracting state constitutes an effective enforcement and remedy mechanism that corresponds to the particularities and special needs of public procurement. ${ }^{44}$ In other words, the correct implementation and enforcement of public procurement liberalisation under the GPA rests on a mechanism stipulated under the GPA itself and substantiated and effectuated through the domestic order of the WTO members who are party to the Agreement. Consequently, the effective application of the GPA is in essence guaranteed through a synergy between the GPA itself and the relevant provisions of each individual domestic order that allow each bidder to challenge any observed irregularities.

3.3 The third level of synergy: using the EU Remedies Directive and the UNCITRAL Model Law as templates for improving the GPA's enforcement system

Finally, although the current bid challenge system under the GPA matches the particular characteristics of public procurement enforce-

\footnotetext{
42 Norway - Tendering Procedures on Trondheim Toll Ring Project: Report of the Panel adopted by the Committee on Government Procurement (13 May 1992) BISD 40S/319. For a summary of the case with an emphasis on its remedies, see Petros Mavroidis, Trade in Goods (OUP 2012) 809.

43 Petros Mavroidis and Bernard Hoekman, 'The WTO's Agreement on Government Procurement: Expanding Disciplines, Declining Membership?' (1995) 63(4) Public Procurement Law Review 69.

44 The particularities of construing appropriate remedies in the field of public procurement stem from the fact that public procuring constitutes a 'a single event, costly to reverse, and where modifications to national rules of general application would not necessarily provide adequate guarantees for non-recurrence'. See Martin Dischendorfer, 'The Existence and Development of Multilateral Rules on Government Procurement Under the Framework of the WTO' (2000) 9 Public Procurement Law Review 1; Patrick Low, Aaditya Matoo and Arvind Subramanian, 'Government Procurement in Services' (1996) 20(1) World Competition 16.
} 
ment, it does show a number of weaknesses. It is therefore worth exploring whether the weaknesses may be adequately addressed through the examples offered by other public procurement remedies systems. Against this background, the present paper submits that a third synergy is being offered by the possible use of the EU Remedies Directive and the UNCITRAL Model Law as templates for improving the GPA's enforcement system. With this proposition in mind, the current section first lays out the various shortcomings of the current bid challenge system before explaining how the aforementioned examples could assist in improving it.

\subsubsection{Shortcomings in the current bid challenge system}

We have already established that the bid challenge system presents an enforcement mechanism that matches the particularities of the public procurement process as a whole. This is not to say, however, that the relevant provisions under the GPA do not entail any weaknesses whatsoever. From a structural perspective, the following points are worth highlighting.

First, according to Article XVIII paragraph 7 of the GPA, each party should adopt or maintain procedures that provide for:

where a review body has determined that there has been a breach or a failure as referred to in paragraph 1 , corrective action or compensation for the loss or damages suffered, which may be limited to either the costs for the preparation of the tender or the costs relating to the challenge, or both" (emphasis added).

Consequently, compensation for a successful challenger is limited to the costs for tender preparation or protest. In light thereof, concerns have been expressed as to whether this measure to claim damages constitutes an incentive that is strong enough to guarantee the correct application of the GPA through private actions. ${ }^{45}$

Second, the Agreement does not provide for or impose any restrictions on the practice of settlements. The prospect of unconditional settlements between procurement officials and potential challengers inevitably affects the enforcement of the GPA. Equally, the possibility of settlements between successful and unsuccessful bidders may lead to 'collusive outcomes' contrary to the GPA's provision. ${ }^{46}$

\footnotetext{
45 Mattoo (n 40): 'the anticipated gain from private action, and the incentives for it, are not very high. Consequently, the scope for private litigation to exercise a socially desirable corrective or deterrent effect is limited' 2 . For a discussion on what remedies would be appropriate, see eg Sue Arrowsmith, The Character and Role of National Challenge Procedures Under the Government Procurement Agreement' (2002) 11 Public Procurement Law Review 235.

46 Xinglin Zhang 'Supplier Review as a Mechanism for Securing Compliance with Government Procurement Rules: A Critical Perspective' (2007) 16(5) Public Procurement Law Review 325.
} 
Last, the enforcement mechanism does not provide for the challenge and judicial review of bail-outs in cases where governments choose to reimburse the unanticipated cost overruns of a firm which has won a procurement contract.

Other than the above architectural elements, the relevant literature also picks up substantive shortcomings. These weaknesses may be summarised as follows: first, the GPA allows for the possibility of entrusting the initial challenge to a non-judicial review body; second, there is ambiguity regarding the extent of the corrective powers of the review bodies, and, especially, whether the review body must have the authority to set aside a signed contract whose award violates the Agreement. ${ }^{47}$

Following the above, empirical research reveals that these shortcomings in the bid challenge system have on many occasions prevented suppliers from bringing infringement proceedings against the contracting authorities before domestic bodies. ${ }^{48}$ In many instances, suppliers have expressed their distrust of the domestic remedies regimes and have noted that they are in any event afraid that any action brought under the domestic review process could jeopardise their prospects of future business and dealings with the competent national authorities. ${ }^{49}$

It therefore arises from the above that, although a step in the right direction, the bid challenge procedure as envisaged in the GPA does not completely address the full range of considerations and concerns related to the Agreement's enforcement and implementation.

In fact, it is less than clear whether the revised GPA has succeeded in remedying the shortcomings laid out above. For example, Reich considers that the modernisation envisaged under the revised GPA has not at all improved the Agreement's enforcement system. ${ }^{50}$ Reich uses three main arguments. First, the updated text does not elaborate adequately on the requisite independence that review bodies need to enjoy. Second, the revised provisions on interim measures do not foresee the right to demand the correction of committed breaches. On the contrary, their objective is to preserve the supplier's 'opportunity to participate in the procurement'. Last, the revised text has relieved the review body from

\footnotetext{
47 Sue Arrowsmith, John Linarelli and Don Wallace Regulating Public Procurement: National and International Perspectives (Kluwer International 2000) 772: the authors note that the review bodies in many countries are indeed reluctant to interfere with contracts already concluded.

48 Reich (n 17).

49 Sue Arrowsmith, The Law of Public and Utilities Procurement (Sweet \& Maxwell 2005) 1435. For an empirical study on the factors why suppliers are reluctant to lodge formal challenges in the context of the EU, see Despina Pachnou 'Bidders' Use of Mechanisms to Enforce EC Procurement Law' (2005) 14 Public Procurement Law Review 256.

50 In fact, in its scoreboard Reich assesses the changes on legal remedies as a failure.
} 
the preliminary duty of examining the merits of the complaint and finding whether a violation of the rules has occurred. Following the above observations, Reich reaches the conclusion that the revised GPA in fact weakens the effectiveness of the GPA's enforcement and remedies system instead of improving it.

Consequently, although the rationale behind the bid challenge system is of a nature and class that reflect the uniqueness of the public procurement procedure, there are nonetheless weaknesses in the mechanism's content and application as laid down under the GPA. Commentators note that these shortcomings have resisted the GPA's recent revision.

\subsubsection{The EU Remedies Directive and the UNCITRAL Model Law as tem-} plates towards the GPA's future improvement

The above sections have established that Article XXVIII GPA, although tuned to the basic characteristics of the public procurement process, nonetheless shows some weaknesses and spots for further improvement. The natural question, then, is what the best and most efficient way would be to address the traced shortcomings within the GPA's bid challenge system.

This paper suggests that the key to improving the GPA's bid system lies in other legal instruments that adopt similar bid challenge systems, namely the EU Remedies Directive and the UNCITRAL Model Law.

For what it is worth, the relevant literature ${ }^{51}$ has already commented on the fact that the foundations of the bid challenge systems under the GPA are quite similar to those under the EU's Remedies Directive on Public Procurement. ${ }^{52}$ With that in mind, reaching out to the remedy mechanisms of the EU Directive gains further legitimacy. And, indeed, the updated remedies system, as prescribed under the EU Directives, rests on three principles that resolve to a great extent the weaknesses traced under the GPA's bid challenge system. In particular, the EU Directive's remedies regime is premised on the following three doctrines:

- The doctrine of standstill periods: no contract should be concluded following an award decision under the procurement rules be-

\footnotetext{
51 See generally Xingling Zhang, 'Constructing a System of Challenge Provisions to Comply with the Agreement on Government Procurement' in Sue Arrowsmith and Robbert D Anderson (eds), The WTO Regime on Government Procurement: Challenge and Reform (CUP 2011) 483.

52 Directive 2007/66/EC of the European Parliament and of the Council of 11 December 2007 amending Council Directives 89/665/EEC and 92/13/EEC with regard to improving the effectiveness of review procedures concerning the award of public contracts (Text with EEA relevance) [2007] OJ L335/31. For an overview, see <http://ec.europa.eu/ growth/single-market/public-procurement/rules-implementation/remedies-directives / index_en.htm> accessed 18 December 2015.
} 
fore the expiry of a 'standstill period' of at least 10 days from the day following the date on which the contract award decision is sent to the 'tenderers concerned'. Tenderers are not 'concerned' if they have previously been excluded and have already been notified of their exclusion.

- The doctrine of contract suspension: the new Remedies Directive requires that once an application for review has been made, the contract under review cannot be entered into until the court has made a decision regarding the application. ${ }^{53}$

- The doctrine of ineffectiveness: the new Remedies Directive states that public contracts will be 'ineffective' where there is a breach of the public procurement rules. ${ }^{54}$

Along the same lines, the UNCITRAL Model Law stipulates a list of available remedies whose range appears to addresses the concerns voiced against the respective remedies system under the GPA. More specifically, according to Article 67(9) of the Model Law, the competent national body may take any of the following actions in deciding on any lodged complaint:

(a) Prohibit the procuring entity from acting, taking a decision or following a procedure that is not in compliance with the provisions of this Law;

(b) Require the procuring entity that has acted or proceeded in a manner that is not in compliance with the provisions of this Law to act, to take a decision or to proceed in a manner that is in compliance with the provisions of this Law;

(c) Overturn in whole or in part an act or a decision of the procuring entity that is not in compliance with the provisions of this Law other than any act or decision bringing the procurement contract or the framework agreement into force;

(d) Revise a decision by the procuring entity that is not in compliance with the provisions of this Law [other than any act or decision bringing the procurement contract or the framework agreement into force];

(e) Confirm a decision of the procuring entity;

(f) Overturn the award of a procurement contract or a framework agreement that has entered into force in a manner that is not in compliance with the provisions of this Law and, if notice of

53 Directive 2007/66/EC, Art 2(3).

54 Directive 2007/66/EC, Art 2(d). 
the award of the procurement contract or the framework agreement has been published, order the publication of notice of the overturning of the award;

(g) Order that the procurement proceedings be terminated;

(h) Dismiss the application;

(i) Require the payment of compensation for any reasonable costs incurred by the supplier or contractor submitting an application as a result of an act or decision of, or procedure followed by, the procuring entity in the procurement proceedings that is not in compliance with the provisions of this Law, and for any loss or damages suffered[, which shall be limited to the costs of the preparation of the submission or the costs relating to the application, or both]; or

(j) Take such alternative action as is appropriate in the circumstances.

What is more, the Model Law also foresees a standstill period between the publication of the award decision and the actual execution of the awarded contract. ${ }^{55}$

\subsubsection{Conclusions}

The above analysis has presented the available remedies under the EU's Remedies Directive and the UNCITRAL Model Law to show that these incorporate and address to a certain extent the concerns and criticisms expressed against the weaknesses of the bid challenge system under the WTO's GPA. Consequently, these could be used as a leading paradigm and inspiration for the GPA's further amendment and development. Following on from this, the general discussion regarding the future improvement of the GPA's bid challenge system reveals yet another shade of synergy between the WTO's GPA and the European and International legal orders. This is so because the EU Remedies Directive and the UNCITRAL Model Law may constitute an inspiration, a benchmark and perhaps a flexible template for the GPA's upcoming revisions of the bid challenge provision.

\section{General Conclusions}

The evolution and development of the WTO's GPA is based on a purely pragmatic approach. The Agreement's shape-taking and expansion have been gradual and escalating: the WTO members and parties to the Agreement submit to the GPA's scope as many areas and subjects as they feel

55 UNICTRAL Model Law, Art 22. 
comfortable with at a time. The GPA has, therefore, been structured in such a way as to follow its parties' needs with each subsequent round of negotiations, revisions or amendments, taking the status quo one step closer to the overarching goal of public procurement liberalisation.

In parallel with this process, however, the interests of public procurement liberalisation are also served through the interaction of the GPA with other international, regional and domestic instruments. This paper has presented and analysed three such instances of synergy created as a result of this interaction, all of which assist in the better application, implementation and enforcement of the principles proclaimed and the provisions enshrined under the GPA. First, the principles, standards and procedures of the GPA are promoted through a number of international and regional texts, including model laws and soft law instruments. Second, the successful enforcement of GPA relies on the remedies systems available under domestic legal orders. Third, the possible improvement of the remedies system under the GPA may be inspired by similar templates offered under other international and regional systems.

Where does all this leave us? It is fairly obvious that public procurement liberalisation is not to be achieved by means of a protracted sprint, but rather through a well-organised and rehearsed marathon. What this article has aimed to highlight, though, is that just like every marathon, the process of liberalising public procurement is not a one-man show. On the contrary, its success relies and rests on the synergies generated from the dialogue and interaction between the actual text of the WTO's GPA and relevant international, regional and domestic instruments. 